\title{
Livestock market of Palangki (1996 - 2017): a study of socio-economic history
}

\author{
Felia Siska1, Siti Fatimah ${ }^{2}$, Buchari Nurdin ${ }^{3}$ \\ ${ }^{123}$ Universitas Negeri Padang, Padang - Indonesia, (feliasiska17@gmail.com)
}

\begin{abstract}
Livestock Market of Palangki is included in Type A's regional livestock markets and categorized as the largest in Central Sumatra. This market has its own uniqueness especially its transactional activity which is also known as "Marosok". This paper was aimed to unveil the secret behind its presistence, until now. This study used a historical method. The result showed that Toke who did transaction in the market were not only from West Sumatera but many of them were also from outside of West Sumatera. Livestock market of Palangki has been surviving until today due to government's role, marketing network between Toke ternak, market security and its strategic location.
\end{abstract}

Keywords : development, toke ternak, marosok, persistence

\section{Introduction}

Traditional livestock market is one of economical supports and closely related to society culture. Marketing process has its own mechanism that forms social structure and market network which is divided into micronetwork dan macronetwork (Baker, 1984).

Traditional market has a long history in giving much constribution for economy of a country (Shakur et al, 2012). A research about traditional market and market regulation was conducted by Steven J. Staal under title "Livestock Marketing and Supply Chain Management of Livestock Products". Staal described about the condition of livestock market in India. He studied about new issues, livestock demands, dairy need supplies, and marketing strategies which had been used since 1980 which enable the market supporting national economy (Staal, 2015). Market develops alongside the local culture of a society (Zakaria et al, 2016).

Massive changes of model and pattern of markets in various regions in West Sumatra does not necessarily overthow the traditional market that has been taking place in people lives. There are some markets which do not go with progress and modernity such as livestock market. According to Presidential Regulation No. 122 Year 2007, the livestock market belongs to government-owned market by type. It still maintains the local culture, values and tradition, for example, Marosok. Marosok is a unique traditional transaction process which has been existing in Minangkabau since a long time ago. Marosok transaction process can avoid price competition and keep the relationship between perpetrators of the livestock market in harmony (Putri, 2015). This transaction system has the function of brotherhood, solidarity, entertainment, and preservation of cultural heritage (Regina, 2017). 
Palangki Livestock Market in Sijunjung Regency is the biggest regional livestock market in central area of Sumatera. livestocks traded in this market are cow and water buffalo. These two types of Livestock are of the best quality in Sijunjung Regency. Cows traded are beef cow type of Simmental O and dan local cow while water buffalos traded are dairy and beef water buffalos (putri,2001). In 2012, sales of livestock per year in Type A regional livestock market in West Sumatera, were approximately 25.000 heads in Palangki livestock market, 20.000 heads in Muaro Paneh livestock market, 20.000 heads in Payakumbuhlivestock market and 15.000 in Cubadak livestock market in Tanah Datar Regency (www.padangtime.com). This data shows that Palangki Livestock Market is the largest in West Sumatera.

Livestock merchants are from outside West Sumatera (South Sumatera, Bengkulu, Jambi, Riau, North Sumatera, Aceh) and from inside West Sumatera Province (Dhamasraya, Sawahlunto, Solok, Tanah datar, Payakumbuh, Padang panjang, Pariaman, Padang and Sijunjung). The reason for the big scope of customers' origins of this market is that Palangki Livestock Market serves as the center of livestock wholesale trade. The stocks in Palangki Livestock Market are not sold to consumers but are commonly sold to retailers from various regions (Yulisman, 2015). This indicates that market networks between toke ternak has been wide and going well that attracts people from various regions in Sumatera. This condition has been around since the market was built in 1996 until 2017.

This study is focused on traditional markets and market regulation. It has been initiated by Steven J. Staalentitled "Livestock Marketing and Supply Chain Management of Livestock Products"about livestock market condition. It analyzed the conditions of livestock in India, where the recent studies show that a demand for livestock to meet the milk needs and marketing strategies undertaken since 1980, so that the livestock market sustains the economy.

Another study on the livestock market in Minangkabau is from article written by Jelly Dwi Putri about "Constuction of Marosok Meaning in Livestock buy and sell at Cubadak Village in Tanah Datar Regency". The results indicate that the transaction "Marosok" is a tradition of buying and selling process that has been existing Minangkabau since ancient times. This such buying and selling can avoid price competition and maintain harmony of relationship between the perpetrators of livestock buying and selling.

A study written by Zusmelia (2007) about "Pasar Nagari Sustainability of Minangkabauin World Economics: A Study Case of Cassiavera Market in Minangkabau, West Sumatra". The results show that the Pasar Nagari as part of traditional market in Minangkabau has trading network accompanied by certain symbols in the transaction of buying and selling of Cassiaverain Pasar Nagari as a unique culture of Minangkabau.

Another research written by Rika Nursanti is titled "Analysis of Livestock Trader Satisfaction Toward Palangki Livestock Market Service in Sawahlunto/Sijunjung Regency of Sumatera Barat Province". The research shows that the factors influencingthe satisfaction of livestock traders are the guarantee of transaction security, officer's hospitality, animal health inspection, clarity of market regulation, the ability of the officer to give information, the presence of officers outside of the market day, the ticket price, the livestock breeding cage, market days of the week and market ability to respond to traders' complaints.

Based on the description of the problem above, research questions were formulated: How can Palangki Livestock Market keep its reputation (presistence) as Type A regional market and as the largest in central area of Sumatera? and What is the effect of the market on socio-economic life and culture of the society?

The purpose of this research was to (1) Analyse the development of Palangki Livestock Market in Sijunjung Regency in economic and social perspectives, (2) Analyse the Effect of the existence of Palangki Livestock Market on socio-economic lives of the people who involve in the market. 


\section{Method}

This study used historical research method and followed three research procedures, namely heuristics, source critic, and historiography. Heuristics was a stage of data collection with the purpose of finding various sources that would support this research, both primary and secondary sources. The primary sources are eyewitnesses' accounts and the secondary sources are the data collected from literature study or information given by non-eyewitnesses (Kuntowijoyo, 1999).

Stage two is source critic. Historical evidence is a collection of facts or historical information which has been verified by validation process which is in history science called source critic. There are two types of source critic, namely internal and external critic. Stage three is interpretation which means interpreting or giving meaning to the facts or historical evidences. In this stage, the researcher analyzes and re-interprets the collected data before writing it into scientific work. The last procedure of a research is writing. In this stage, confirmed facts and data which are the fragments of events that have not yet been intact information are described and written in the form of research report or scientific work.

\section{Discussion}

\section{Development of Livestock Market}

The result of this research showed the development (from 1996 to 2017) as the largest regional market in central area of Sumatera which was studied in three periode of time: early period (19962003), transitional period (2004-2009) and period of Tanjung Udani Livestock Market (2010-2017).

In ealy period, the condition of market was in the state of physical development, Toke Ternak who came to Palangki Livestock Market were mostly from outside West Sumatera Province, and market revenues continued to increase. In the next period (transitional) Palangki livestock market was overloaded so that the market had to be rebuilt in a new location. Toke Ternak were mostly from inside the Province and they bought livestocks from stockbreeding center located in outside the Province. Livestocks in the market were $89.67 \%$ brought from outside the Province and $10.33 \%$ were from inside the Province. Palangki Livestock Market is a transit point for livestocks entering West Sumatera.

The development of livestock market is inseparable from the role of actors who play in the market of livestock. Since the livestock market of Palangki was established in 1996, it come a livestock market that a "toke-toke ternak" stopover from various regions, the livestock entering west Sumatra transit at the livestock market of Palangki, then distributed to various regions. Market conditions as described by Slater and Tonkiss that the basic function of the market is where to sell, but they interpret the wider with interaction and exchange. Damsar also said that the functioning of market institutions as an economic institutions is inseparable from the activities undertaken by buyer and Toke Ternak.

The market is meant by Slater and Tonkiss that the markets as an additional function of cultural exchanges that accur in the market. The condition livestock market of Palangki, in addition to the market for livestock, there are special symbol livestock market of Palangki percerived by Toke. The codes of ethics that are built but latent, such as the level of Toke in the market, without any standard rules. Then formed of built due to interaction between traders, in terms of traders who status as a buyer and also as a seller, so that the livestock market is developed into the largest regional market in Central Sumatra. In addition, Slater and Tonkis share market functions of marketplace, one of which is the market as a system/place that has its own size (highly regulated). It is this market function that characterizes the livestock market is West Sumatra, including the Palangki. Livestock markets have their own systems in the process of buying and selling, the interactions that is built within the market both between the actors who play the role and the community around the livestock market. 
The development livestock market of Palangki is also inseparable from the theory of social change, meaning thath changes that occur in society certainly affect tha activity in the market because market actors are part of the community structure. Social Change Theory proposed by Selo Soemardjan and Soelaeman Soemardi that changes in the society will involve may things and about the norms, value, patterns of people's behavior, organization, composition and stratification of society. The process of development of the livestock market from the beginning built in 1996 until 2017, there are values that are built in the interaction in the market that is familiar with the code of ethics market. Toke Ternak in the market (Toke Balai) controls the Toke intermediaries or agents coming from the villages, but this condition is no longer valid since the behavior change in the community about the use of electronic media Mobilphone because all traders have been able to communicate with agents and breeders through Mobilphone without having to bring the livestock directly to the cattle market.

\section{Persistence of Livestock Market}

Supporting factors that maintain the reputation of the market as the largest regional livestock market in West Sumatera are:

\section{Government Role}

Palangki Livestock Market is a market which is managed by government of Sijunjung Regency or Sawahlunto Sijunjung Regency (the name before 2005) and has been operating since January, $3^{\text {rd }}$ 1996. Its inauguration as livestock market was held on December, 27th 1995 with the Decree of the Regent of Sawahlunto/Sijunjung Regency level IINumber 188.45/628/SK-Bpt/1996 (The Regent of SWl/Sijunjung Regency,1995).

In term of its facility and infrastructure, buyers and sellers, the number of transaction, and management, Palangki Livestock Market was in good condition. These could not be separated from the role of local government, in this case Livestock and Fishery Sector, who fully contributed towards Palangki Livestock Market. The government's commitment is visible in the vision, mission, motto, promise and edict of Palangki Livestock Market.

\section{Livestock Market Networks}

The Following chart shows types of patterns and market networks applied in Palangki Livestock Market from 1996 - 2017.

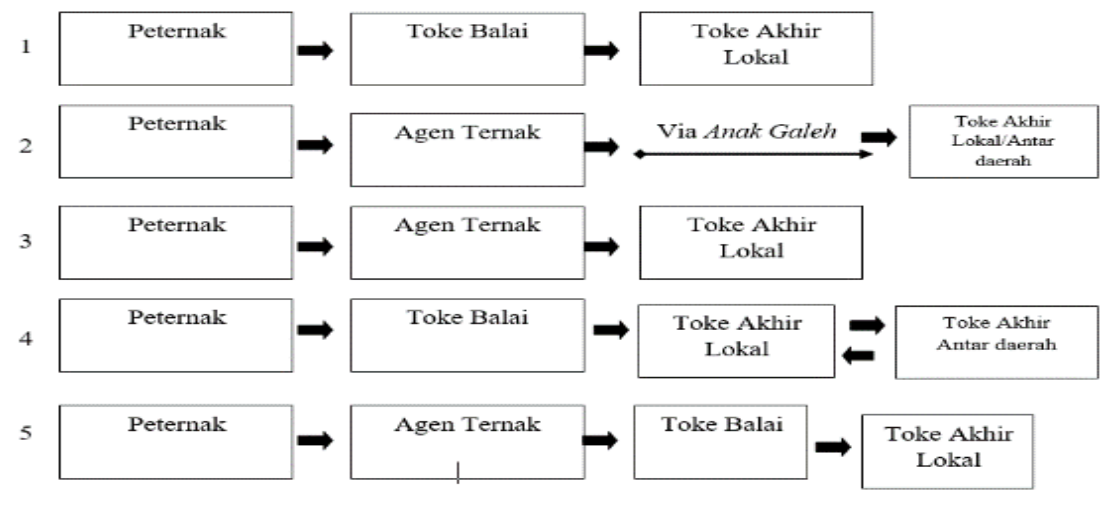

Source : Processed data from interview with Kj, $\mathrm{Hr}$ on $16^{\text {th }}$ of September and $3^{\text {rd }}$ of October 2017.

According the pattern and the flow of livestock sales in Palangki Livestock Market since 1996, in the past Toke directly bought the livestocks from the breeders. However, Toke had difficulty in collecting the livestocks from breeders in Sijunjung Regency since they had to visit every house. Therefore, Palangki Livestock Market was built so that the stockfarmers can directly sell their stocks in the market. The stocks are sold to Toke Balai in Palangki Livestock Market. In 1996-1997 Palangki Livestock Market was still in the testing phase and its facility and infrastructure were 
very simple and still at the stage of development process. So, there were only few toke that came to the market and the stocks were available only for the area around West Sumatera.

\section{Market Location}

Based on findings from the field, one of the factors that make Palangki Livestock Market to be the largest Type A regional livestock market in central area of Sumatera is its strategic location on the side of Sumatera Highway, that is $11 \mathrm{~km}$ far from Padang. In addition, it is also located in segitiga emas area, a meeting point of three provinces (Sumbar - Riau -Jambi). This makes Palangki Livestock Market easily accessed by stock sellers and buyers who especially come from West Sumatera and generally come from Sumatera Island in accordance to its regional scale level (Yulisman, 2015).

Other than that, Palangki Livestock Market is also near the areas of livestock market suppliers in West Sumatera, for example Kumanis Sumpur Kudur livestock market, Sijunjung livestock market, Gunung Medan Dhamasraya livestock market, Muaro Paneh livestock market in Solok Regency, Cubadak Batu Sangkar livestock market, Payakumbuh livestock market and other areas. Kumanis Sumpur Kudus livestock market is the main buffer market for Palangki Livestock Market. Since Palangki Livestock Market is regional market, as a local livestock market, Kumanis livestock market help keeping the balance of Palangki's dynamic supply dan demand related to the condition and situation.

\section{Market Security}

Based on the information from informants, the researcher found a uniqueness of Palangki market concerning to its security system. It is said that the security of the sellers is guaranteed by Association of Livestock Traders, the security team who is appointed by market managers and local people, which is headquartered in Palangki livestock market. The sellers feel at ease and do not worry if a problem occurs in the transaction because the association will help solving the problem. The market security is described in the following chart:

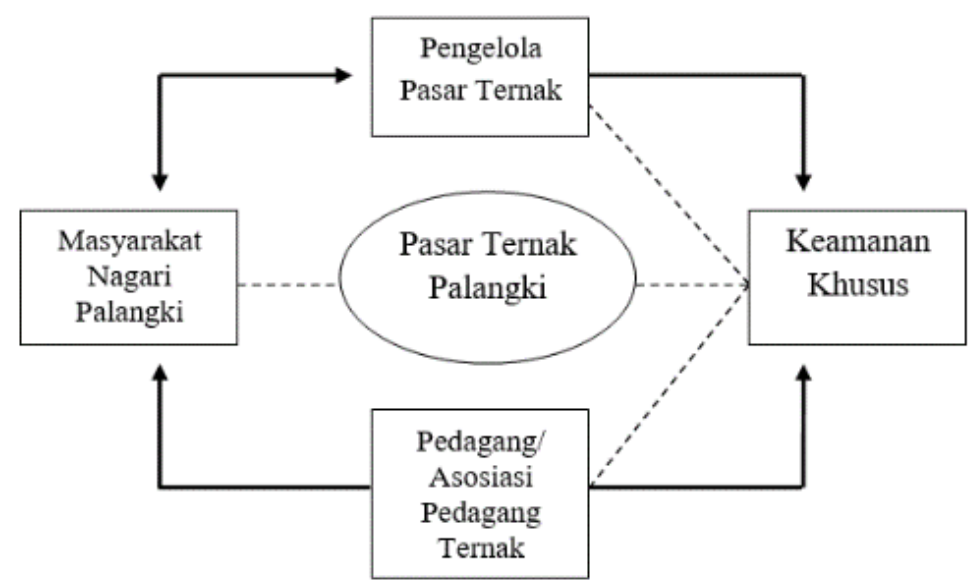

Source : processed data from interview with merchants, managers and special security, 2017

\section{The Effect of Livestock Market}

\section{Toke Ternak}

Palangki Livestock Market is one of traditional market. According to Nusyirwan Effendi, the actors who involve in traditional market are 1). Local people, they develop collaboration in the production phase, 2) merchants, they distribute commodities/stocks in the marketing centers/markets, 3). Transport providers, they deliver the commodities and fill the range of paths 
of commodity dispersal. (Efendy, 2016). In other words, the actors or toke who participate in traditional market are mostly local people who live around the market or around the regency.

In the case of Palangki Livestock Market, Effendy in his research explained that one of the actors who participate in the market is toke ternak, including toke perantara (mediator), toke balai, toke akhir lokal and toke antar daerah. The ones who play a major role in the market are toke perantara and toke balai who are the people of Sijunjung Regency. Meanwhile, toke akhir lokal and toke antar daerah are the ones who have big capitals. They are small in number compared to the first two toke. Palangki Livestock Market is a media for all toke trading their stocks. It has positive effect on economic life of Toke Ternak, where they can easily marketing their stocks. The more transaction the more their profit.

\section{AnakGaleh}

The existence of anak galeh is also very important for the development of Palangki Livestock Market. Anak Galeh is responsible for keeping, feeding and taking care of the stocks so that they have high selling point. The stocks checked in the market will be taking care by Anak Galeh who are mostly local people who live around District of IV Nagari. However, there are some stock merchants from outside the region who bring their own caretaker who will take care of their stocks in the market. The toke prepare bedeng or dangau (a small space or room) for Anak Galeh to relax and take a rest. They are usually paid as much as Rp. 300.000 per week. Sold or not, Anak Galeh still receive their salary.

Anak Galeh also understandhow to take a good care of the stocks, are able to recognize the livestock disease and know how to give first aid if something happen to the stocks. Moreover, anak galeh is very skill at cleaning and polishing the cattle horns because the better their appearance the more expensive their price. In the interview between researcher and Arisman, who works as Anak Galeh, he stated that not everyone can be Anak Galeh because this job requires patience and skill. According to researcher's analysis, this might be the reason why many merchants from outside the region decide to bring their own right-hand men to take care of their stocks in Palangki Livestock Market before being sold to the buyers or consumers.

Palangki Livestock Market affects economic and social lives of Anak Galeh. Since the establishment of the market, many jobs are available for the society that their standard of living is increasing as they have a steady income. Other than taking care, grassfeeding and bathing cattle, capable, skilled and honest Anak Galeh are trusted by their boss or. Anak Galeh are trusted topick the cattle from stockfarmers in the villages, deliver the cattle to buyer's address and sell the stocks in ordinary days if anyone want to buy the cattle. These activities can give an additional income for Anak Galeh. Other than that, they can also do part time job such as collecting the grass and selling as fodder in the livestock market (Interview with Sahap, October $4^{\text {th }}, 2017$ ).

\section{Food Vendors}

The existence of Palangki Livestock Market has been giving many opportunities for people to earn a living, for example for vendors. Some of them open the food stalls around the market. Even some of the stalls are built inside the market.

When the market was built in 1996 at Jorong Tambang Ameh Nagari Palangki, there were only few stalls around the market. Then, following the development of the market, many stalls were opened because many visitors came to Palangki Livestock Market. Furthermore, some local people also offered transportation services or livestock transport services with the result that people's income increased. 


\section{Nagari Income (local income)}

Palangki Livestock Market also has an effect on regional income of Nagari Palangki. Merchants or sellers who did the transaction in the market agreed to pay Rp 500 per head for Nagari. Income earned from Palangki Livestock Market is used by local government (Nagari) to build nagari's facilities and infrastructures such as mosque renovation, road construction, and other public facilities.

\section{Conclusion}

Based on the problem elaborated and discussed by theories, concept, and experts' opinion, the conclusion can be drawn as follow: The development of Palangki Livestock Market from 1996 to 2017 as the largest regional market in the central area of Sumatera was studied in the three period of time. They are early period (1996 - 2003), transitional period (2004 - 2009) and period of Pasar Ternak Tanjung Udani (2010 - 2010).

Next, presistence supporting factors of Palangki Livestock Market from 1996 to 2017 are: The management of Palangki Livestock Market is supervised by local government through UPTD (the technical implementation unit) of Palangki Livestock Market. The provision of facility and infrastructure is according to standard of Type A regional livestock market. Then, market network between toke is wide and going well so that the market has many visitors. In addition to that, the market is build in a strategic location, that is in the side of Sumatera Highway which is easily accessible from many areas. Moreover, Palangki Livestock Market is safe and comfortable until toke ternak do not worry to trade their stocks.

The effects of Palangki Livestock Market are1) for Toke Ternak, there is an increase in their economic lives, 2)for Anak Galeh, it helps their family economy, Anak Galeh is a pioneer to become Toke in livestock market, 3) for community around the market, they utilize the market for selling foods, fodder, and animal medicine, and 4) for Nagari Palangki's Income, it increases regional income of Nagari Palangki.

\section{References}

Damsar. (2002). Sosiologi Ekonomi. Jakarta: PT Raja Grafindo Persada.

Douglass C. North, "Market and Other Allocation System In History: The Challenge Of Karl Polanyi" Journal Of European Economic History. 6(3): 707.

F.Madarisa, et al. (2012). "Potret Pasar Ternak Sumatera Barat". Jurnal Peternakan Indonesia. 14(3): 433-440.

Jelly Dwi Putri. (2005). "Kontruksi Makna Marosok Dalam Transaksi Jual Beli Ternak di Desa Cubadak Kabupaten Tanah Datar" Jurnal Jom Fisip UNRI. 2 (1): 1-15.

Khalilah Zakariya et al. (2012). Sustaining The Cultural Vitality Of Urban Public Market : A Case Study Of Pasar Payang, Malaysia. Jounal Archnet-IJAR: International Journal of Architectural Research 10(1): 228-239.

Kuntowijoyo. (1999). Pengantar IlmuSejarah. Yogyakarta: Yayasan Bentang Budaya.

Nusyirwan Efendi. (1996). Masyarakat Ekonomi Minangkabau. Padang: Makalah FakultasI lmu Sosial dan Politik Universitas Andalas.

Nusyirwan Efendi. (2016). Studi Budaya Pasar Tradisonal dan Perubahan Gaya Hidup Masyarakat Pedesaan :Kasusdan Masyarakat Nagari di Provinsi Sumatera Barat. Jurnal Antropologi : Isu-isu Sosial Budaya18 (2): 105-120. 
Regina. (2017). "Tradisi Marosok Dalam Transaksi Jual Beli Ternak Di Pasar Ternak Kota Payakumbuh, Sumatera Barat". Jurnal Jom Fisip UNRI. 4(2): 1 - 15.

Shakur, T., Hafiz, R., Vural-Arslan, T. \& Cahantimur, A. (2012). Economy And Culture In Transitions: A Comparative Study Of Two Architectural Heritage Sites Of Bazaars And Hans Of Bursa And Dhaka. Journal Archnet- IJAR: International Journal of Architectural Research, 6(3): 1-18.

Soejono Soekanto. (2014). Sosiologi Suatu Pengantar. Jakarta: PT Raja Grafindo Persada

Steven J. Staal. (2015). Livestock Marketing And Supply Chain Management Of Livestock Products. Journal: Indian Journal Of Agricultural Economics. 70(1): 43-63.

Vanda Rilla Nusa Putri. (2000). "Analisis Situasi Pasar Ternak Palangki Kecamatan IV Nagari Kabupaten Sawahlunto Sijunjung Provinsi Sumatera Barat". Unpublished undergraduated thesis. Bogor : Institut Pertanian Bogor.

Wayne E. Baker. (1984). "The Social Structure Of A National Securities Market", American Journal of Sociology. 89(4): 771-782.

Yulizar. (2015). Profil Pasar Ternak Palangki tahun 2015. Sijunjung: Dinas Peternakan Kabupaten Sijunjung.

Zusmelia. (2007).“Ketahanan (Persistence) Pasar Nagari di Minangkabau dalam Ekonomi Dunia: Kasus Pasar Kayu Manis (Cassiavera) di Minangkabau, Provinsi Sumatera Barat". Unpublished dissertation (Bogor: Sekolah Pasca Sarjana Institut Pertanian Bogor. 